\title{
Application of Electrical Impedance Measurements' Method for Studies of Bubble Flows
}

\section{I.A. Konovalov, A.A. Chesnokov, A.A. Barinov, S.M. Dmitriev, A.E. Khrobostov,} M.A. Makarov

Nizhny Novgorod State Technical Univercity n.a. R.E. Alekseev, Minin str., 24, Nizhny Novgorod 603950, Russia

Received 28.09.2021

Accepted for publication 06.10.2021

\begin{abstract}
One of the important tasks in carrying out a computational justification of the reliability and safety of equipment that is part of the projected nuclear power plants today is the modeling of the bubbly regime of the coolant flow. In this regard the aim of this work is the use of extended methods of using matrix conductometric systems which are widespread in research practice for study of gas-liquid flows.

The work uses a method of primary processing of experimental data aimed at eliminating of excess conductivity in the cells of the developed wire mesh sensor which makes it possible to obtain the values of the true volumetric gas content in the investigated area.

Subsequent analysis of the possibilities to estimate the volumes of registered gas bubbles by the gradient method as well as the size of the interface in the sensor cells which plays a key role in modeling the interfacial heat and mass transfer.

Comparison of readings values with the control instruments cues showed a good agreement. The presented work is an adaptation of the use of a conductometric measuring system for the study of multicomponent flows with the aim of further application for the study of two-component flows in the channels of the core simulator using wire mesh sensors.
\end{abstract}

Keywords: wire mesh sensor, two-layer wire mesh sensor, bubble flow.

DOI: $10.21122 / 2220-9506-2021-12-3-183-193$

\footnotetext{
Адрес для переписки:

Коновалов И.А.

Нижегородский государственный технический университет,

ул. Минина, 24, г. Нижний Новгород 603950, Россия

e-mail: iliakonowaloff@yandex.ru

Для цитирования:

I.A. Konovalov, A.A. Chesnokov, A.A. Barinov, S.M. Dmitriev,

A.E. Khrobostov, M.A. Makarov.

Application of Electrical Impedance Measurements' Method

for Studies of Bubble Flows.

Приборы и методы измерений.

2021. - T. 12, № 3. - C. 183-193.

DOI: $10.21122 / 2220-9506-2021-12-3-183-193$
}

Address for correspondence:

Konovalov I.A.

Nizhny Novgorod State Technical Univercity,

Minin str., 24, Nizhny Novgorod 603950, Russia e-mail: iliakonowaloff@yandex.ru

For citation:

I.A. Konovalov, A.A. Chesnokov, A.A. Barinov, S.M. Dmitriev,

A.E. Khrobostov, M.A. Makarov.

Application of Electrical Impedance Measurements' Method

for Studies of Bubble Flows.

Devices and Methods of Measurements

2021, vol. 12, no. 3, pp. 183-193.

DOI: $10.21122 / 2220-9506-2021-12-3-183-193$ 


\title{
Применение электроимпедансного метода измерений при исследовании пузырьковых режимов течения двухкомпонентного потока
}

\author{
И.А. Коновалов, А.А. Чесноков, А.А. Баринов, С.М. Дмитриев, А.Е. Хробостов, \\ М.А. Макаров
}

Нижегородский государственный технический университет имени Р.Е. Алексеева, ул. Минина, 24, г. Нижний Новгород 603950, Россия

Поступила 28.09.2021

Принята к печати 08.10.2021

Одной из важных задач при проведении расчётного обоснования надёжности и безопасности оборудования, входящего в состав проектируемых ядерных энергетических установок, на сегодня является моделирование пузырькового режима течения теплоносителя. В связи с этим, целью данной работы являлось изучение особенностей движения газового пузыря в жидкой среде, а также отработка и расширение методических особенностей применения матричных кондуктометрических систем, получивших широкое распространение в исследовательской практике, для исследования газожидкостных потоков.

В работе изложен способ первичной обработки экспериментальных данных, направленный на устранение избыточной проводимости в ячейках разработанного сетчатого датчика, что позволило получить значения истинного объёмного газосодержания в исследуемой области.

Последующий анализ позволил оценить объёмы регистрируемых газовых пузырей градиентным методом, а также величину плотности межфазной поверхности в ячейках датчика, которая играет ключевую роль при моделировании межфазного тепло- и массообмена.

Сравнение полученных величин с показаниями контрольно-измерительных приборов экспериментальной установки показало хорошую степень соответствия. Представленная работа является адаптацией применения кондуктометрической измерительной системы для исследования многокомпонентных потоков с целью дальнейшего применения для исследования двухкомпонентных потоков в каналах имитатора активной зоны при помощи сетчатых кондуктометрических датчиков.

Ключевые слова: сетчатый кондуктометрический датчик, двухслойный датчик, пузырьковое течение.

DOI: $10.21122 / 2220-9506-2021-12-3-183-193$

Нижегородский государственный технический университет,

ул. Минина, 24, г. Нижний Новгород 603950, Россия e-mail: iliakonowaloff@yandex.ru

Для цитирования:

I.A. Konovalov, A.A. Chesnokov, A.A. Barinov, S.M. Dmitriev,

A.E. Khrobostov, M.A. Makarov.

Application of Electrical Impedance Measurements' Method

for Studies of Bubble Flows.

Приборы и методы измерений.

2021. - T. 12, № 3. - C. 183-193.

DOI: $10.21122 / 2220-9506-2021-12-3-183-193$
}

Address for correspondence:

Konovalov I.A.

Nizhny Novgorod State Technical Univercity,

Minin str., 24, Nizhny Novgorod 603950, Russia e-mail: iliakonowaloff@yandex.ru

For citation:

I.A. Konovalov, A.A. Chesnokov, A.A. Barinov, S.M. Dmitriev,

A.E. Khrobostov, M.A. Makarov.

Application of Electrical Impedance Measurements' Method

for Studies of Bubble Flows.

Devices and Methods of Measurements.

2021, vol. 12, no. 3, pp. 183-193.

DOI: $10.21122 / 2220-9506-2021-12-3-183-193$ 


\section{Introduction}

Justification of the reliability, safety and efficiency of nuclear power plant circuits is an important task for developers. The success is directly related to the introduction of new technical solutions which in turn require a preliminary numerical simulations.

The operating modes of power equipment are determined by a set of hydrodynamic processes often accompanied by the presence of a two-component flow. For example some Russian projects of low and medium power NPPs use gas pressurizers which causes the dissolution of $N_{2}$ in the primary coolant. During normal operation of the system, the concentration of dissolved gas in the pressurizer and the primary coolant comes to a certain stationary distribution, however power variation and a change in the primary coolant temperature in a number of modes causes the release of a gas phase as well as a change in the conditions of gas solubility in the coolant, which can lead to a violation in the operation of the primary circuit equipment:

- loss of head, deviation from the nominal characteristics during the operation of the circulation pumps;

- deterioration of heat transfer, entailing wall boiling on the fuel element cladding, which leads to an increase in temperature and the risk of local burnout with subsequent corrosion;

- disturbances in the operation of control and measuring devices.

In addition there is a problem of studying the structure of a gas-liquid flow, since two-component flows play a major role in such processes as cavitation, bubbling and many others. In particular, the hydrodynamics of gas-liquid flows determines the operability of some passive safety systems for promising nuclear power plants of low and medium power.

These phenomena require the solution of an extensive number of computational problems aimed at substantiating the reliability and safety of nuclear power plants, taking into account the presence of two-component flows in their elements. The solution of these problems with the use of computational fluid dynamics (CFD) programs requires the determination of the interphase surface necessary for calculating the mass and energy fluxes across the interface $[1,2]$. At the same time, the need to test the predictive ability of the mathematical models requires the development of experimental methods for measurements in twophase flows.

In research practice to study the hydrodynamic characteristics of flows in the elements of power plants, the method of matrix conductometry is widely used. The measuring system built on its basis is used, in particular, as part of several validation test facilities [3, 4].

Thus the purpose of this work was to study the features of the movement of a gas bubble in a liquid medium as well as to develop and expand the conductometric methodology for gas-liquid flows investigations.

\section{Test facility}

To track the motion of a single bubble, the method of matrix conductometry [5] was used in this work which is based on the measurement of the conductivity of the medium at the sensor points. Conductometric measuring system consists of the impedance measurement system LAD-36 [6] and 2-layer wire mesh sensor (WMS) depicted at the Figure 1.
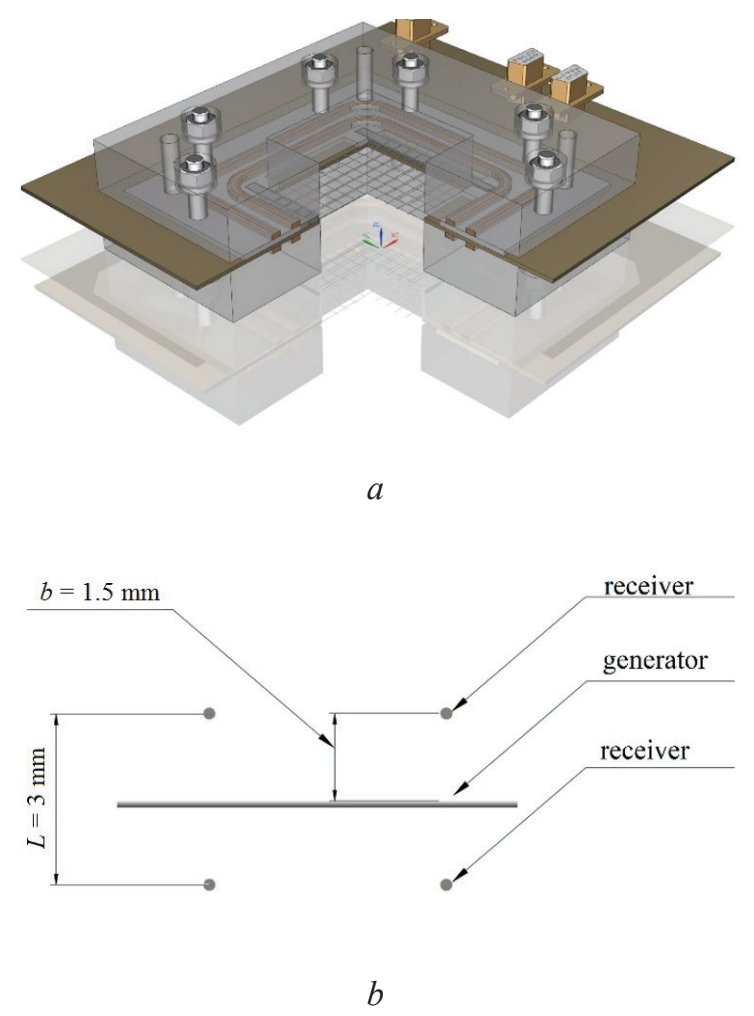

Figure 1-Schematic representation of a two-layer sensor: $a$-general view of a two-layer wire mesh sensor; $b$-spatial arrangement of the wire mesh sensor electrodes 
The use of two layers of cells formed by the three layers of wire electrodes makes it possible to place two measuring planes in one housing with a small axial distance which allows to estimate the velocity of single bubbles [7]. It should be noted that within the framework of the investigations the application of the conductometry method was used

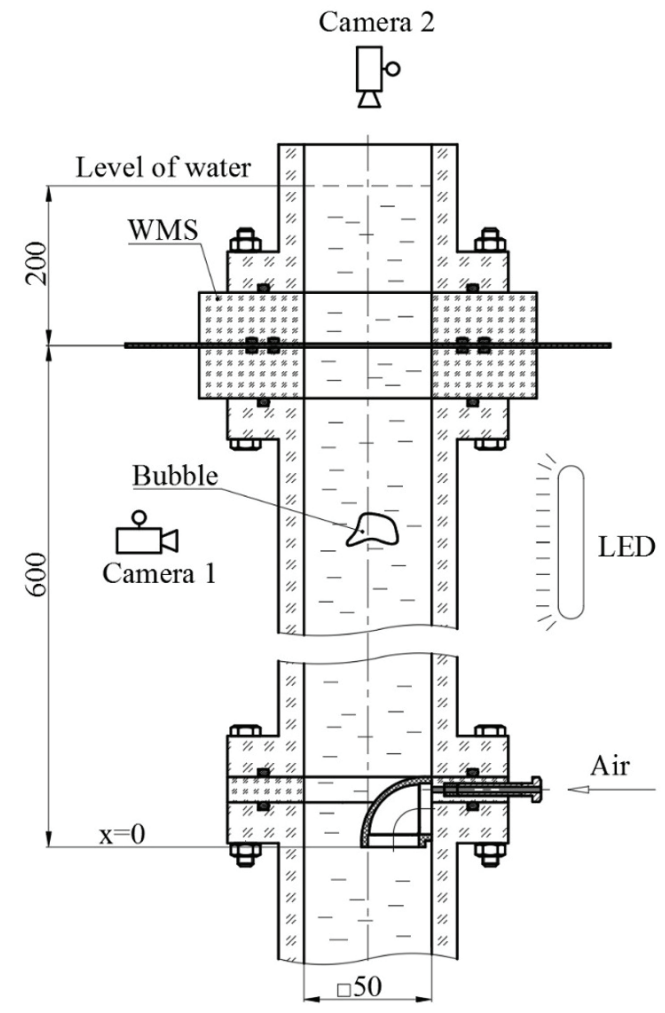

$a$ for determining the presence or absence of electrical impedance in the considered measurement region.

The experimental section included a square channel with a two-layer mesh conductometric sensor a bubble injection system, LED illumination and external video camera. The experimental setup is shown schematically at the Figure 2.

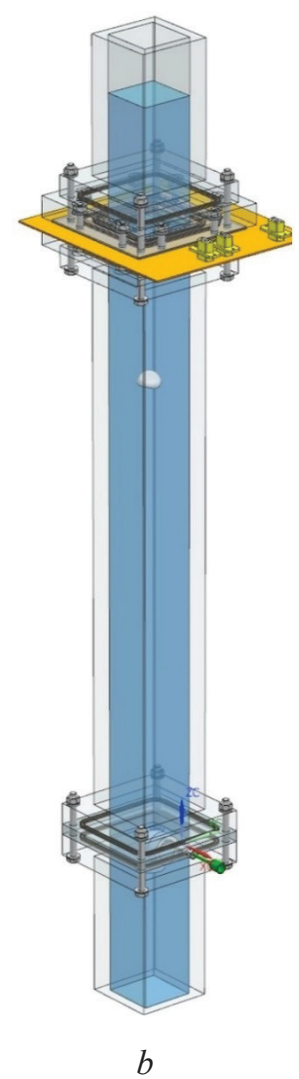

Figure 2 - Experimental setup: $a$ - sketch of the test section; $b$ - general view of the test model

The mesh sensor was installed $600 \mathrm{~mm}$ above the injection section. The arrangement and numbering of the WMS cells are shown at the Figure 3.

One of the main tasks in a similar experimental setup is the creation of sufficiently large gas bubbles that can be accurately identified by a mesh sensor with a given resolution. In this work injection facility was made as a bend with $20-\mathrm{mm}$ diameter directed downward (Figure 4). When gas is supplied to the injection tube the surface tension forces of the water hold the bubble at the bend's outlet until it becomes large enough for the buoyancy force to prevail over the surface tension forces. This mechanism ensures the creation of bubbles of approximately the same size having a diameter of about 3-4 WMS cells in the cross section of the channel.
Figure 5 shows a the growth of a gas bubble in the injection section before separation and subsequent emergence.

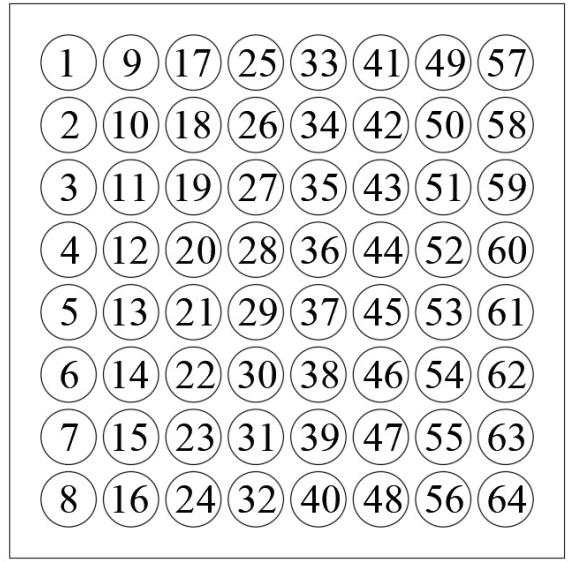

Figure 3 - Accepted cell numbering of the measuring area of the wire mesh sensor 


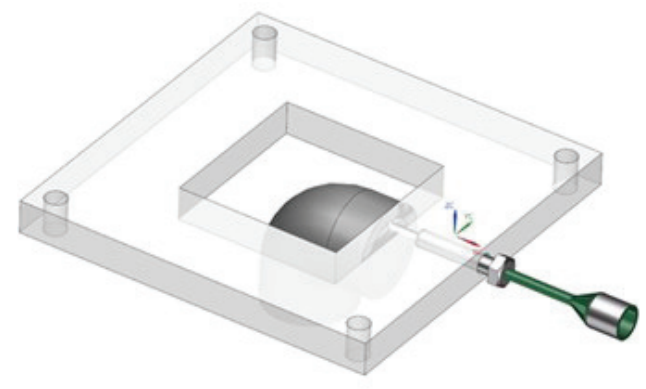

Figure 4-General view of the injection section

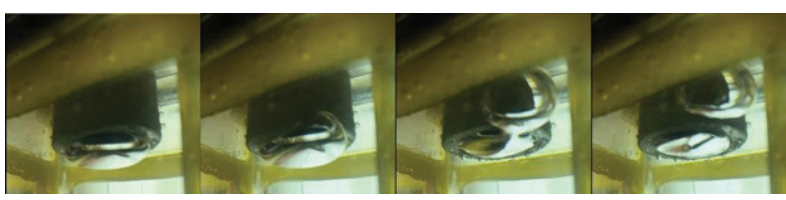

Figure 5 - Growth of a gas bubble before separation and subsequent

Video record was carried out at a frequency of 60 frames per second. The LED backlight was used to increase the contrast of the image.

\section{Setting up an experiment}

A series of experimental studies carried out at this work were aimed primarily at the testing of the WMS and measurement system to track the 2-phase flows. In this regard the experimental modes were organized in two ways:

- detection of the passage of single bubbles through the mesh sensor was used to debug the algorithm for the primary processing of experimental data;

- detection of the passage of a series of bubbles through the WMS with a known amount of gas injected into the model during the experiment. This tests were used to debug the algorithms for identifying the time intervals for the implementation of the conductivity corresponding to the passage of the bubble through the WMS, as well as for the direct assessment of the bubble volume.

The test model was filled with a tap water (conductivity $\approx 800 \mu \mathrm{S} / \mathrm{cm}$ ) with the level maintained at $200 \mathrm{~mm}$ above the WMS. Atmospheric air was used as a gas phase due to its low solubility at room temperature. As a result the interfacial mass transfer was neglected in the experiments.

The test parameters are summarized in Table 1 .
Table 1

Parameters of the tests

\begin{tabular}{ccccc}
\hline No & $\begin{array}{c}\text { Number } \\
\text { of bubbles } \\
\text { larger than } \\
5 \mathrm{~mm}\end{array}$ & $\begin{array}{c}\text { Total } \\
\text { volume of } \\
\text { injected } \\
\text { gas, ml }\end{array}$ & $\begin{array}{c}\text { Tempe- } \\
\text { rature, } \\
{ }^{\circ} \mathrm{C}\end{array}$ & $\begin{array}{c}\text { Duration, } \\
\mathrm{s}\end{array}$ \\
\hline 1 & 5 & 9.0 & 28.3 & 30 \\
2 & 5 & 9.0 & 27.9 & 30 \\
3 & 5 & 9.0 & 27.5 & 30 \\
\hline
\end{tabular}

\section{Method of experimental data processing}

The primary data are the values of the absolute conductivity of the medium $G_{i, j, z, k}[\mu \mathrm{S}]$, obtained bythe LAD-36 system and software package FT40-WMS. Here $i$ is the number of the generator electrode (by $X$ axis), $j$ is the number of the receiver electrode (by $Y$ direction), $z$ is the number of the WMS layer (by $Z$ axis), $k$ is the number of the measurement sample.

In the ideal case the value $G_{i, j, z, k}$ will be determined only by the intrinsic resistance of the medium in the measuring cell of the sensor however in practice the recorded conductivity also includes components depending on the resistance of the WMS electrode material uneven distances between the electrodes of receivers and generators over the cross section as well as the presence of various deposits on the surface of the electrodes.

In order to exclude the influence of these values on the experimental data, a preliminary calibration of the WMS was carried out. Due to the fact that conductivity of the air can be neglected, the calibration procedure takes the form:

$$
g_{i, j, z, k}=\frac{G_{i, j, z, k}}{\overline{G_{i, j, z}^{c a l}}},
$$

where $\overline{G_{i, j, z}^{c a l}}$ is the averaged value of the fluid conductivity in the cell $\{i, j, z\}$ during calibration, $\mu \mathrm{S}$.

For the assessment $\overline{G_{i, j, z}^{c a l}}$ a calibration measurement of the absolute steady state conductivity $G_{i, j, z, k}^{c a l}$ of the liquid was used:

$\overline{G_{i, j, z}^{c a l}}=\frac{1}{N_{c a l}} \sum_{k=1}^{N_{c a l}} G_{i, j, z, k}^{c a l}$,

where $N_{c a l}$ is the number of the calibration counts. 

$30 \mathrm{~s}$.

Duration of the calibration measurements was

Subsequent analysis of the experimental data showed the presence of a local increase in conductivity exceeding the conductivity of the liquid phase when the gas bubble approaches the measuring plane of the WMS - hereinafter referred to as "overshoots" of conductivity. A similar phenomenon was observed in [8]. An example of test data with conductivity overshoots is shown in Figure 6.

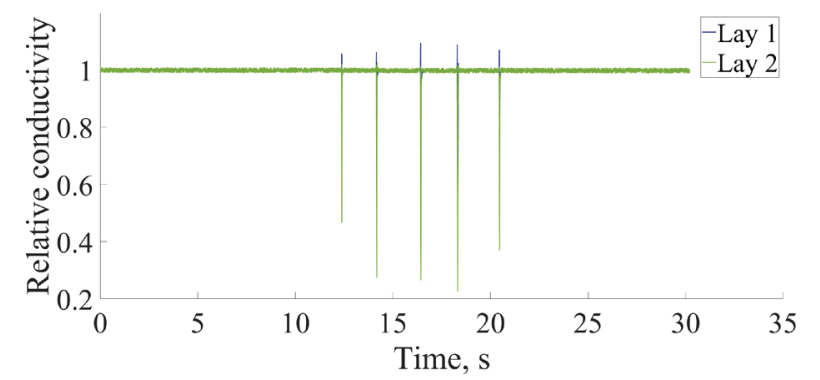

$a$

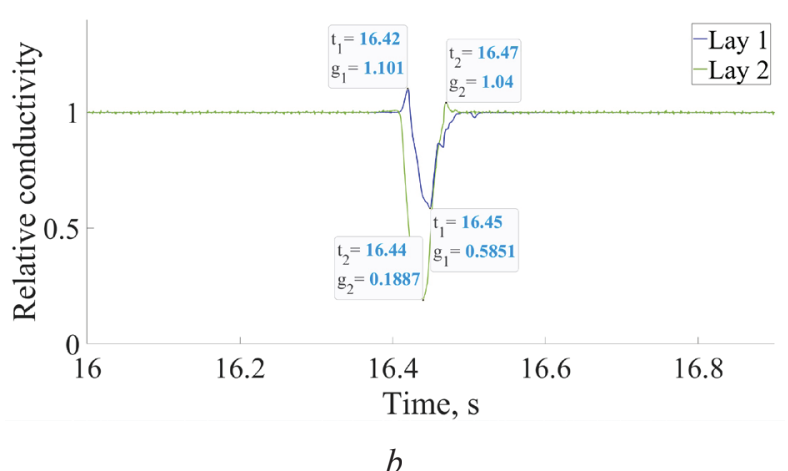

Figure 6-Typical signal with conductivity overshoots (cell 27) in experiment N1: $a$ - general view of the signal realization; $b$ - detail view of peak of conductivity corresponding to $3 \mathrm{rd}$ bubble passing through wire mesh sensor

The nature of overshoots can be explained by the violation of the symmetry of the measuring cell. In other words the presence in the neighboring cell of a certain amount of gas not large enough to come into contact with both the generating and receiving electrodes and as a consequence of this a sharp increase in its resistance will cause an increase in the current through the cell under consideration which in in turn will cause a local increase in the measured conductivity.

In most works aimed at studying gas-liquid flows, such conductivity overshoots are eliminated by methods one way or another based on the "linear cut" method [9] in which the local instantaneous gas content is calculated as:

$\varepsilon_{i, j, z, k}=\left\{\begin{array}{l}1, g_{i, j, z, k}>1 ; \\ 1-g_{i, j, z, k}, 0 \leq g_{i, j, z, k} \leq 1 ; \\ 0, g_{i, j, z, k}<0 .\end{array}\right.$

However from the point of physics this procedure is not fully justified since it leads to a violation of the of conductivity balance at the WMS plane. In addition in [10] it was shown that the elimination of conductivity overshoots by the linear cut method leads to an overestimation of the value of the instantaneous local gas content when using mesh sensors.

In this work it is proposed to use the method of rebalancing conductivities [8] modified by taking into account the features of the used measuring system. Let's consider it in more detail.

In accordance with the above reasons for the occurrence of overshoots it seems logical to redistribute the excess conductivity in the cell under consideration (donor cell) over the neighboring cells in which the conductivity $g_{\text {rec }}<1$ (receptor cells). In [8] it was also noted that the occurrence of an overshoot in the donor cell may be due to the cumulative effect of several cells which gives space for the development of more advanced rebalancing models. In this work it was assumed that the occurrence of excess conductivity in a cell is influenced by only 26 neighboring cells forming so-called "cubic Moore neighborhood" (Figure 7).

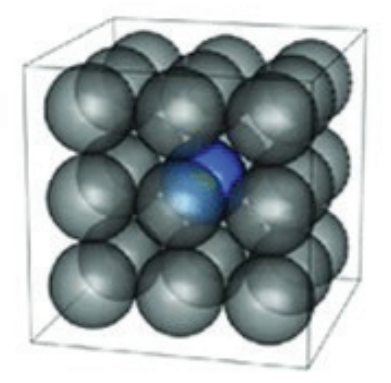

Figure 7-Graphic representation of the Moore neighborhood for the selected point (highlighted in blue)

Rebalancing of conductivities is carried out as follows:

$g_{\text {rec }, \text { cor }}=\left\{\begin{array}{l}g_{\text {rec }}+g_{\text {don }}-(1+0.5 \cdot \sigma), g_{\text {rec }}+g_{\text {don }} \leq 2+\sigma ; \\ 1, g_{\text {rec }}+g_{\text {don }}>2+\sigma\end{array}\right.$ 


$$
g_{\text {don, }, \text { cor }}+0.5 \cdot \sigma=\left\{\begin{array}{l}
1, g_{\text {rec }}+g_{\text {don }} \leq 2+\sigma ; \\
g_{\text {don }}+g_{\text {rec }}-(1+0.5 \cdot \sigma), g_{\text {rec }}+g_{\text {don }}>2+\sigma,
\end{array}\right.
$$

where $\sigma-\mathrm{a}$ parameter characterizing the intrinsic noise of the measuring system, which makes an additional contribution to the conduction overshoot (i. e., is added to $g_{\text {don }}$ ).

The value $\sigma$ is determined from the calibration measurements:

$\sigma_{i, j, z}=\frac{\max \left(G_{i, j, z}^{c a l}\right)}{\overline{G_{i, j, z}^{c a l}}}-1$.

The procedure for rebalancing conductivities (4) and (5) is performed as long as the excess conductivity exists in the donor cell. At each iteration the Moore space cell with the lowest conductivity is selected as the receptor cell.

It can be shown that the total conductivity of the receptor and donor cells in this case will not change, for this we sum up equations (4) and (5):

$$
g_{d o n, c o r}+g_{\text {rec }, \mathrm{cor}}=\left\{\begin{array}{l}
g_{\text {rec }}+g_{d o n}, g_{\text {rec }}+g_{d o n} \leq 2 ; \\
g_{d o n}+g_{\text {rec }}, g_{\text {rec }}+g_{d o n}>2 .
\end{array}\right.
$$

Nevertheless, situations are possible in which the assumption about the influence of only neighboring cells is incorrect (due to the geometry of the measuring region, etc.). In this case the conductivity overshoot cannot be completely eliminated by the rebalancing method, as a result of which it is advisable to use a threshold filter with a width $K_{t} \cdot \sigma$ (along the ordinate), where $K_{t}$ is the tuning coefficient determined during calibration; for the considered experiments $K_{t}=1.02$. An example of realizations of conductivity before (overshoots of conductivity greater than 1 are visible) and after the rebalancing procedure is shown at the Figure 8. The designated points form the Moore neighborhood for a point with conductivity $g=1.05$.

The values of the relative local conductivity obtained after filtration $g_{i, j, z, k}^{\text {cor, filt }}$ can be used to determine the instantaneous volumetric gas content according to Maxwell's rule:

$$
\varepsilon_{i, j, z, k}=\frac{1-g_{i, j, z, k}^{\text {cor }, \text { filt }}}{1+0.5 \cdot g_{i, j, z, k}^{\text {cor filt }}} \text {. }
$$

In Figure 9, an example of the gas bubble passage is depicted.

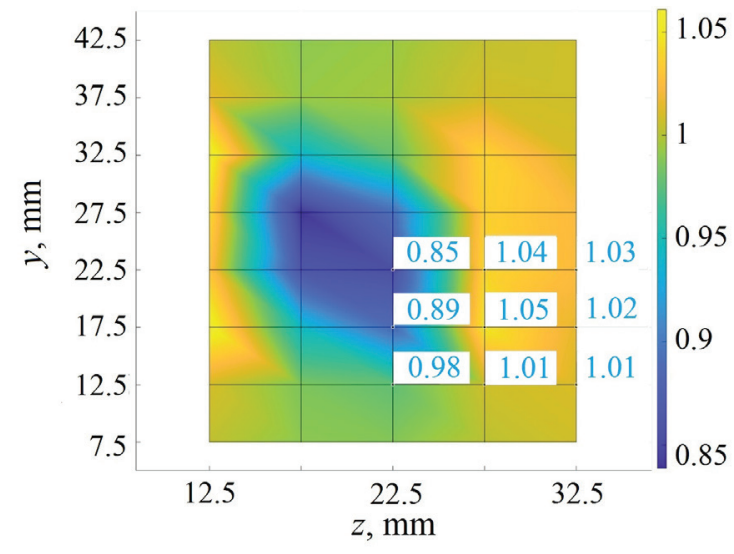

$a$

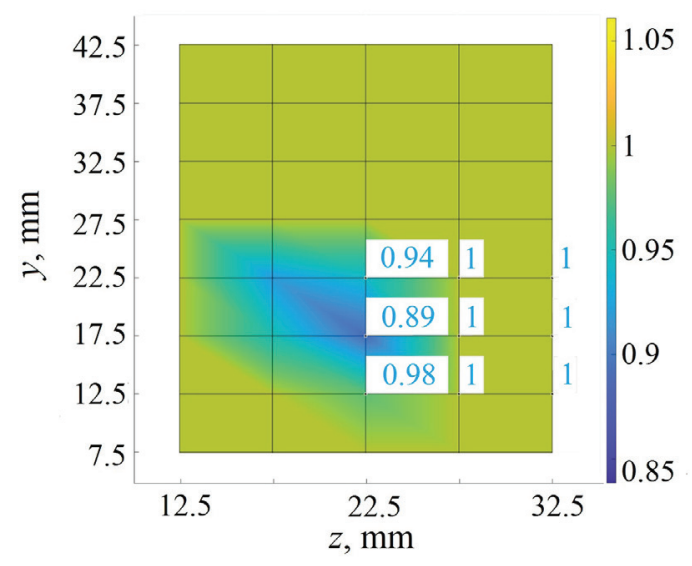

$b$

Figure 8 - Measured conductivity field before and after rebalancing and filtration (cell 27) in experiment N1: $a$ - signal before rebalancing and filtering; $b$ - signal after rebalancing and filtering

As mentioned above one of the practical applications of studying bubble flows is to determine the density of the interphase surface which is used in calculations to determine the interfacial heat and mass transfer.

Knowing the distribution of some scalar quantity $\phi(x, y, z, t)$, depending on the phase state of the medium, it's gradient magnitude will be written in the form:

$a(x, y, z, t)=|\nabla \phi(x, y, z, t)|=\sqrt{\left(\frac{\partial \phi}{\partial x}\right)^{2}+\left(\frac{\partial \phi}{\partial y}\right)^{2}+\left(\frac{\partial \phi}{\partial z}\right)^{2}}$.

Thus, the value is different from 0 along the interfacial surface, thereby its physical meaning can be interpreted as the "amount" of an interfacial surface area contained in a unit volume - the density of the interfacial surface. In this case, it's dimension is $\frac{m^{2}}{m^{3}}=\left[\frac{1}{L}\right]$. 


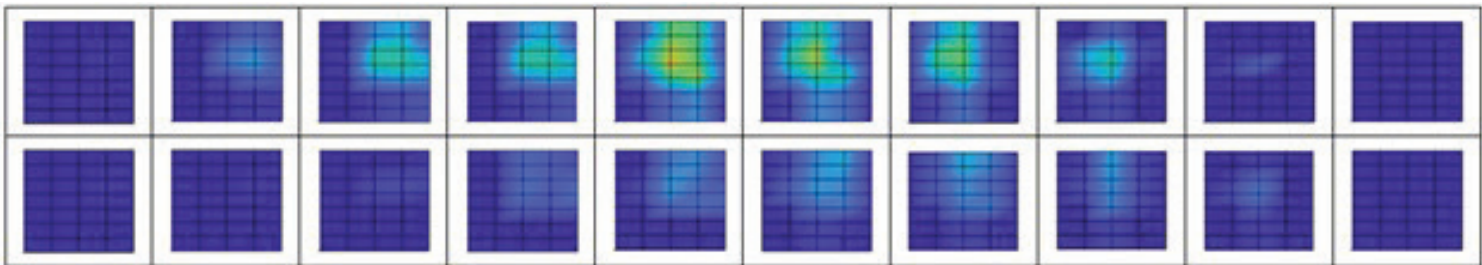

Figure 9 - Gas bubble passage: top row - layer 1; bottom row - layer 2 in experiment N1 (interval $8.2 \mathrm{~ms}$ ). The vertical lines are generators wires, the horizontal - the receiver electrodes

Replacing $\phi$ the relative electrical conductivity of the medium $g$ also depends on the phase state of the medium for the volumetric gas content conductometric sensor and can be written as:

$\varepsilon_{i, j, z, k}=\frac{1}{\Delta x \Delta y \Delta z \Delta t} \int_{x}^{x+\Delta x} \int_{y}^{y+\Delta y} \int_{z}^{z+\Delta z} \int_{t}^{z+\Delta t} g(x, y, z, t) d x d y d z d t,(10)$ where $\Delta x, \Delta y, \Delta z$ are the distance between the measuring cell in the directions of $X, Y$ and $Z$ respectively, $\mathrm{m} ; \Delta t$ is time step, $\mathrm{s}$.

Now, using expression (10) we express $a$ through the distribution $\varepsilon$. For an ideal conductometric sensor (no space-time sampling):

$\lim _{\substack{\Delta x \rightarrow 0 \\ \Delta y \rightarrow 0 \\ \Delta z \rightarrow 0 \\ \Delta t \rightarrow 0}}\left|\nabla \varepsilon_{i, j, z, k}^{i d e a l}\right|=\lim _{\substack{\Delta x \rightarrow 0 \\ \Delta y \rightarrow 0 \\ \Delta z \rightarrow 0 \\ \Delta t \rightarrow 0}}\left|\nabla \frac{1}{\Delta x \Delta y \Delta z \Delta t} \int_{x}^{x+\Delta x} \int_{y}^{y+\Delta y} \int_{z}^{z+\Delta z} \int_{t}^{t+\Delta t} g(x, y, z, t) d x d y d z d t\right|=|\nabla g(x, y, z, t)|=a(x, y, z, t)$.

In turn, for a real WMS with spatial and temporal sampling of indications, expressions (9) and (11) are converted to the form:

$a_{i, j, k}=\sqrt{\left(\frac{\Delta \varepsilon_{i, j, z, k}}{\Delta x}\right)^{2}+\left(\frac{\Delta \varepsilon_{i, j, z, k}}{\Delta y}\right)^{2}+\left(\frac{\Delta \varepsilon_{i, j, z, k}}{\Delta z}\right)^{2}}$.

The derivatives of the gas content $\frac{\Delta \varepsilon_{i, j, z, k}}{\Delta x}$, used in expression (12) were calculated using finite difference schemes [11]:

$$
\begin{aligned}
& \frac{\Delta \varepsilon_{i}}{\Delta x}=\frac{\varepsilon_{i+1}-\varepsilon_{i}}{\Delta x} ; \\
& \frac{\Delta \varepsilon_{i}}{\Delta x}=\frac{\varepsilon_{i+1}-\varepsilon_{i-1}}{2 \Delta x} ; \\
& \frac{\Delta \varepsilon_{i}}{\Delta x}=\frac{-\varepsilon_{i+1}+8 \varepsilon_{i+1}-8 \varepsilon_{i-1}+\varepsilon_{i-2}}{12 \Delta x},
\end{aligned}
$$

where $x$ is direction along the considered coordinate axis.

Scheme (13) was used to calculate the derivatives in the extreme cells of the WMS in $X$ and $Y$ as well as in the axial flow direction (along $Z$ ) since the design of the used two-layer WMS assumes the presence of only two measuring planes in the $Z$ direction. Scheme (14) was used to calculate the derivatives with respect to $X$ and $Y$ in the cells preceding the boundary cells. Scheme (15) for calculating the derivatives with respect to $X$ and $Y$ in the central cells.

The experiments showed that when calculating $a_{i, j, k}$ according to expression (12), it is more expedient to use the values of the volumetric gas content $\varepsilon_{i, j, z, k}$, calculated from the first layer of measuring cells ( $z$ equal to the position of the first layer), since when the bubble collides with the electrodes, it deforms and breaks (Figure 10), which introduces a certain error in the values $\varepsilon_{i, j, z, k}$, recorded by the second layer of cells.
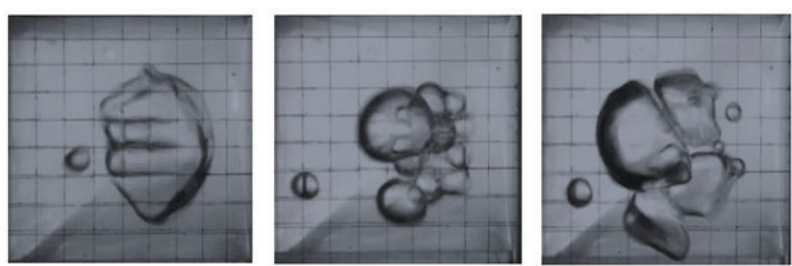

Figure 10 - Crushing and reorganization of a gas bubble passing through the wire mesh sensor

In verification practice, it is more convenient to link density interfacial surface with the observed parameters. Since $a$ has a dimension $\left[\frac{1}{L}\right]$ it is possible to express the area of the bubble surface equivalent to the gas content in the cell: 


$$
A_{i, j, k}=a_{i, j, z, k} \cdot \Delta x \Delta y\left[w_{b u b} \cdot \Delta t\right]
$$

where $w_{\text {bub }}$ - the velocity of bubbles, $\mathrm{m} / \mathrm{s}$.

Then the total bubble surface area will be equal to the sum of the areas determined for each sensor cell during the bubble passage:

$$
A_{b u b}=\sum_{i, j, k} a_{i, j, z, k} \cdot \Delta x \Delta y\left[w_{b u b} \cdot \Delta t\right] .
$$

In expressions (16) and (17) the distance $\left[w_{b u b} \cdot \Delta t\right]$ is used instead of the cell height $\Delta z$. This is due to the fact that the unit volume occupied by the bubble at a given time is not equal to the total volume of the cell $\Delta x \Delta y \Delta z$. The velocity of a single bubble was determined from the time difference between the positions of the gas content maxima determined from the first and second layers of the WMS:

$$
w_{b u b}=\frac{\Delta z}{\mid k_{1}^{\max (\varepsilon)}-k_{2}^{\max (\varepsilon) \mid \cdot \Delta t},}
$$

where $k$ is the number of the reference of the temporary implementation.

In the general case in the process of bubble emerging a sufficiently large bubbles undergo deformation caused by the presence of frontal resistance as well as by the formation of a vortex street behind it. The formation of a vortex wake during the movement of a gas bubble is illustrated in Figure 11.

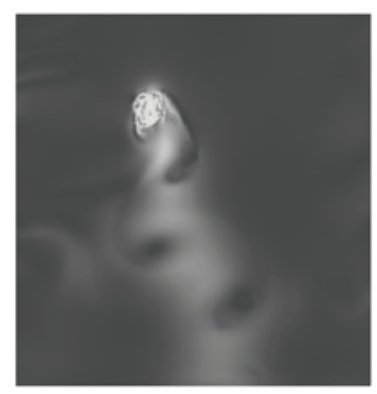

Figure 11 - The velocity field of a bubble with a diameter of $5 \mathrm{~mm}$ [12]

uncer

However, the volume of the bubble $V_{b u b}$ can be expressed in terms of the radius of the equivalent spherical bubble:

$$
V_{b u b}=\frac{4}{3} \pi\left(R_{b u b}^{e q}\right)^{3}
$$

Expressing $R_{b u b}^{e q}$ through $A_{b u b}$ and substituting in (19), we get:

$$
V_{b u b}=\frac{4}{3} \pi\left(\sqrt{\frac{A_{b u b}}{4 \pi}}\right)^{3} \text {. }
$$

The summation of the obtained bubble volumes over all the bubbles recorded during the measurement period makes it possible to compare the gas volume determined from the WMS readings with the total gas volume introduced into the model (obtained from the readings of the injection system instrumentation).

\section{Analysis of the obtained results}

As a result of the experimental data analyses estimates of the velocities volumes and equivalent radii of gas bubbles were obtained. For convenience the data obtained are summarized in Table 2.

The design of the mesh sensor does not allow to record the immediate moment of the bubble passing through the measuring plane - in experiments, the area of the video camera is located up to the mesh sensor. As a result the bubble velocity was estimated as the average value over all injected bubbles. A storyboard for filming a single bubble ascent is shown in Figure 12.

The velocities obtained using expression (18) are consistent with the data of the video camera. Deviations about $17 \%$ can be explained by the uncertainty in the measurement of a wire axial distance.

Table 2

Summary table of experimental research results

\begin{tabular}{cccccc}
\hline No & $\begin{array}{c}\text { Average ascent rate } \\
\text { of a single bubble } \\
\text { (WMS), m/s }\end{array}$ & $\begin{array}{c}\text { Average ascent } \\
\text { rate of a single } \\
\text { bubble (chamber), } \\
\mathrm{m} / \mathrm{s}\end{array}$ & $\begin{array}{c}\text { Average } \\
\text { volume of a } \\
\text { single bubble } \\
\text { by (20), ml }\end{array}$ & $\begin{array}{c}\text { Average volume } \\
\text { of a single bubble } \\
\text { according to } \\
\text { instrumentation, ml }\end{array}$ & $\begin{array}{c}\text { Total volume } \\
\text { of injected gas } \\
\text { (WMS), ml }\end{array}$ \\
\hline 1 & 0.31 & 0.27 & 1.51 & 1.80 & 7.575 \\
2 & 0.33 & 0.27 & 1.50 & 1.80 & 7.482 \\
3 & 0.33 & 0.29 & 1.45 & 1.80 & 7.251 \\
\hline
\end{tabular}




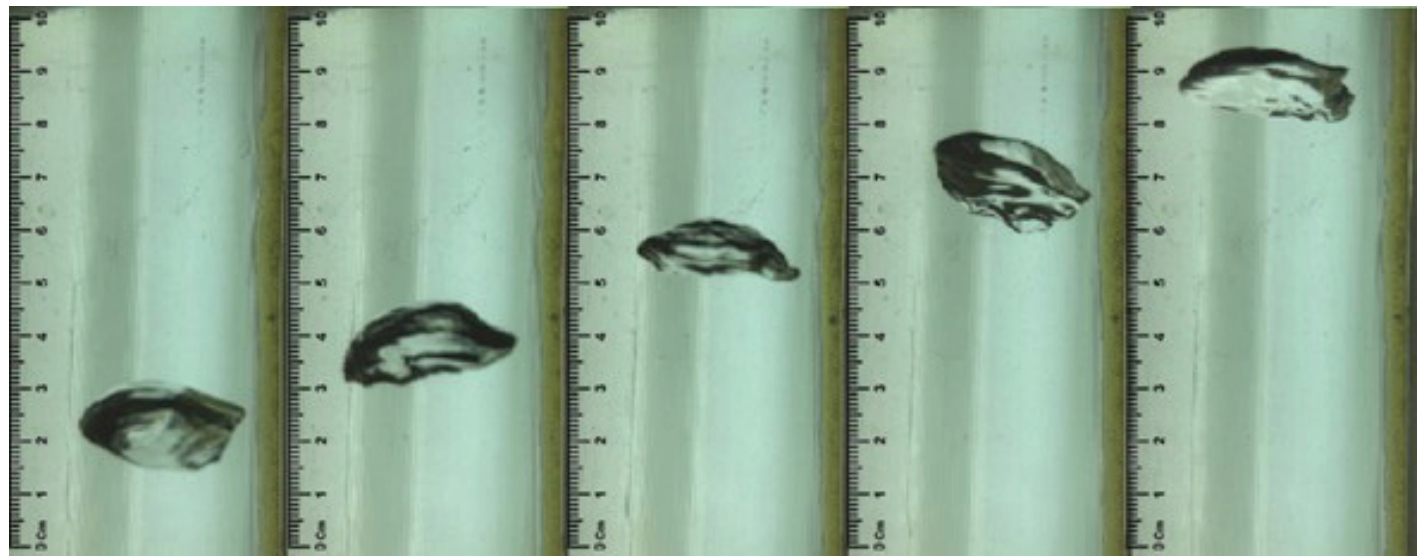

Figure 12 - The emergence of a single bubble (interval $0.05 \mathrm{~s}$ )

At the same time the values of the total gas volume passed through the WMS, are 15-20\% lower than the values for the instrumentation. In general an underestimation of the gas volume indicates an underestimation of the gas content in the section of the WMS. An analysis of the frame samples based on the WMS data shows that in most cases large gas bubbles when passing through the mesh sensor touch the area near the channel wall where the registration of the conductivity is not carried out (due to the construction of the WMS) which can also be the reason for underestimating of the total gas volume.

In addition low spatial resolution of the WMS (in those cases when the ratio $R_{b u b} / \Delta, \Delta=\Delta x=\Delta y$, where $R_{b u b}$ - the radius of the bubble in the cross section is less than a certain value which is a criteria for the given task) increases imprecision in the determination of the derivatives gas content (13)(15) which affects by the value of the density of the interface (12).

\section{Conclusion}

Analysis of the experimental data made it possible to reveal the formation of the excess conductivity during the passage of a gas bubble caused by a violation of the symmetry of the electromagnetic field of the measuring cell due to a significant difference in the conductivity of the liquid and gas phases at the moment when the gas bubble does not completely occupy the cell. The method of conductivity rebalancing used in the analysis of experimental data made it possible to reduce the influence of this phenomenon on the calculated values of the gas content. In view of the fact that the formation of the conductivity overshoot is actually caused by the influence of a complex set of sensor cells the improvement of methods aimed at eliminating these overshoots is an urgent task for further research in this area and can be associated, in particular with the use of approximation algorithms based on convolutional neural networks well adapted to work with data in matrix form.

As a result of applying the method of rebalancing conductivities to the experimental data, the values of the true volumetric gas content in the measuring cells of a two-layer mesh sensor were obtained. In addition the velocity of single bubble was estimated from the wire mesh sensor data and video camera recording.

The obtained values were used to determine the values of the interfacial areas, as well as the volumes of single bubbles by the gradient method, which made it possible to compare the balance values of the gas flow rate according to the readings of mesh sensors and test facility instrumentation.

\section{References}

1. Kataoka I., Ishii M., Serizawa A. Local formulation and measurements of interfacial area concentration in two-phase flow. International Journal of Multiphase Flow, 1986, vol. 12, pp. 505-529.

DOI: $10.1016 / 0301-9322(86) 90057-1$

2. Hibiki T., Ishii M. Two-group interfacial area transport equations at bubbly-to-slug flow transition. Nuclear Engeneering and Design, 2000, vol. 202, pp. 39-76. DOI: 10.1016/S0029-5493(00)00286-7

3. Dmitriev S.M., Barinov A.A., Dobrov A.A., Doronkov D.V., Pronin A.N., Ryazanov A.V., Solncev D.N., Sorokin V.D., Khrobostov A.E. [Experimental Studies of Turbulent Coolant Mixing in the Main 
Equipment of Nuclear Units]. VANT. Seriya: Yadernoreaktornie konstanti [VANT. Series: Nuclear reactor constants], 2018, no. 3, pp. 3-11 (in Russian).

4. Prasser H.M., Kleim S. Coolant mixing experiments in the upper plenum of the ROCOM test facility. Nuclear Engineering and Design, 2014, vol. 276, pp. 30-42. DOI: 10.1016/j.nucengdes.2014.05.016

5. Prasser H.M., Bottger A., Zschau J. A new electrode-mesh tomograph for gas-liquid flows. Flow Measurement and Instrumentation, 1998, vol. 9, pp. 111-119. DOI: 10.1016/S0955-5986(98)00015-6

6. Khrobostov A.E., Legchanov M.A., Solncev D.N., Barinov A.A., Konovalov I.A., Chesnokov A.A., Makarov M.A. [Research of Hydrodynamics of Stratified Turbulent Flows for Validation of Designated Approaches to Modeling Thermal Processes in Equipment of Nuclear Power Plants]. Trudi NGTU im. R.E. Alekseeva [Transactions of NNSTU n.a. R.E. Alekseev], 2019, vol. 126, no. 3, pp. 111-119 (in Russian).

7. Waite B.M., Prasser H.M., Podowski M.Z. Computational and Experimental Analysis of Gas/Liquid Two-Phase Flow in Rod Bundles with Mixing-Vane Spacer Grids. Nuclear Engineering and Design, 2020, vol. 360, pp. 1-42. DOI: 0.1016/j.nucengdes.2019.110499
8. Prasser H.M., Matthias B., Dirk L. Improvement of Topflow Void Fraction Data Using Potencial Field Simulation of th Wire-Mesh Sensor. Specialists Workshop on Advanced Instrumentation and Measurement Techniques for Experiments related to Nuclear Reactor Thermal Hydraulics and Severe Accidents, 2019, vol. 35, pp. 1-16.

9. Beyer M., Lucas D., Kussin J. Quality check of wire-mesh sensor measurements in a vertical air/water flow. Flow Measurement and Instrumentation, 2010, vol. 21, pp. 511-520.

DOI: $10.1016 /$ j.flowmeasinst.2010.09.001

10. Tompkins C., Prasser H.M., Corradini M. Wiremesh sensors: A review of methods and uncertainty in multiphase flows relative to other measurement techniques. Nuclear Engineering and Design, 2018, vol. 337, pp. 205-220. DOI: 10.1016/j.nucengdes.2018.06.005

11. Prasser H.M., Stucki S., Betschart T., Eisenberg J. Interfacial area density measurement using a three-layer wire-mesh sensor. NURETH-16, 2015, pp. 403-418.

12. Clift R., Grace J.R., Weber M.E. Bubblrs, drops and particles. London: Academic Press, 1978, vol. 94, $380 \mathrm{p}$. 